Emilija Beker Pucar ${ }^{1}$

Olgica Glavaški

University of Novi Sad, Faculty of Economics in Subotica
ORIGINAL SCIENTIFIC ARTICLE doi: 10.5937/ekonomika2002001B

Received: December, 23. 2019. Accepted: February, 14. 2020.

\title{
EUROZONE NON-OPTIMALITY: AN OCA BASED ANALYSIS
}

\begin{abstract}
This paper deals with the reconsideration of crucial Optimum Currency Area (OCA) criteria observing Eurozone (EZ) members in the period 2007-2018. According the aim to highlight key obstacles to EZ optimality, economies are mainly grouped into the core and peripheral countries of the initial 12 EZ members (EZ12), and subsequently joined 7 Emerging European Economies (EZ19). The research is based on descriptive analysis of openness and production diversification, macroeconomic divergences and heterogeneity of EZ members, labor mobility and wage flexibility, as well as political OCA criteria. While EZ was not initially constituted as an OCA, this research has confirmed persistent difficulties in EZ functioning in the (post) crisis period. Macroeconomic divergences between member states, insufficient labor mobility and wage flexibility, as well as the absence of political will towards creation of more efficient fiscal union, are identified as the main challenges of EZ sustainability.
\end{abstract}

Key words: Eurozone, labor mobility, wage flexibility, openness, product diversification, political criteria.

JEL classification: F45, F36, E52.

\section{НЕОПТИМАЛНОСТ ЕВРОЗОНЕ: АНАЛИЗА БАЗИРАНА НА ОЦА ТЕОРИЈИ}

\begin{abstract}
Апстракт
У овом раду се разматрају круцијални критеријуми теорије оптималне валутне зоне (ОЦА) из угла земаља чланица Еврозоне (ЕЗ) у периоду 2007-2018. У складу са ичиьем откривања кључних препрека оптималности Е3, економије су груписане на земље језгра и периферије инициалних чланица (Е312), и касније прикључених 7 емергентних европских економија (Е319). Истраживање је базирано на дескриптивној анализи отворености и производне диверзификације, макроекономским дивергенцијама и хетерогености чланица E3, мобилности радне снаге и флексибилности надница, као и политичким ОЦА критеријумима. Иако ЕЗ није иничијално конституисана као ОЦА, ово истраживање потврђује перзистентне потешкоће у функиионисању E3 у (пост)кризном периоду. Макроекономске дивергениије између земаља чланицุ, недовољна мобилност радне снаге и флексибилност надница, као и од-
\end{abstract}

\footnotetext{
${ }^{1}$ emilijabp@gmail.com, ORCID ID 0000-0002-6369-3225,

22 glavaski.olgica@gmail.com, ORCID ID 0000-0001-6628-2301
} 
суство политичке воље ка креирању ефикасније фискалне уније, идентификовани су као главни изазови одрживости Е3.

Кључне речи: Еврозона, мобилност радне снаге, флексибилност наднича, отвореност, производна диверзификаиија, политички критеријуми.

\section{Introduction}

The architects of the Maastricht Agreement considered sharing the same currency as another step on the road to fuller economic integration. By completing two important steps in introducing a common currency, in 1999 and 2002, the EU countries achieved full economic integration. It has been the largest monetary integration since the unification of the United States into a monetary union more than two centuries ago, with the dollar as a single currency. However, sharing the same currency is not easy and has not contributed to economic harmony.

In analyzing the monetary union in Europe, it is necessary to return to the original work of Mundell (1961), proponent or so-called "godfather" of the Eurozone (EZ). Mundell described Optimum Currency Area (OCA) as the region or area where the benefits of sharing a common currency outweigh the costs, that is, the area where the single currency creates the greatest economic efficiency or benefit. In his view, a group of countries form an OCA if the benefit from eliminating currency conversion costs outweighs the cost of not being able to stabilize country-specific shocks under a union. Generally accepted OCA criteria are: capital mobility, labor mobility, price/ wage flexibility, risk-sharing system between regions (fiscal transfers), as well as relative similarity of economic cycles between regions.

Many economic theorists and researchers, including Mundell, considered the EZ an ideal candidate for OCA testing in the years leading up to the 2007-08 global crisis. More recently, however, doubts have been raised as to whether the EZ is at all able to maintain the criteria necessary for the OCA, notably given the significant economic divergence of its members. Since its inception (1999), the EZ has been faced to two major shocks: the global 2008 economic crisis and the debt 2010 European crisis. After the outbreak of the global economic crisis and the debt crisis in Europe, the problems of the EZ have come to the fore. EZ has not been created as an OCA, while mentioned global and European shocks with the asymmetric effects to its members, only amplified this vulnerability. In this paper the EZ is analyzed in the light of the fulfillment of the traditional OCA criteria. Main hypothesis is that EZ cannot be regarded as an OCA, specifically due to: (i) persistent macroeconomic divergences between member states; (ii) insufficient labor mobility and wage flexibility; (iii) the absence of political will towards creation of more efficient fiscal union. In order to shed more light into these beliefs, an empirical study is based upon descriptive analysis of the available OCA criteria in the period 2007-2018 for current 19 EZ members (EZ19). The research period was selected in accordance to the availability of OCA variables at Eurostat database, as well as the fact that Emerging European Economies - EEEs (formerly transition countries) began accession to the EZ since 2007. EZ members are first divided into the core and the periphery. These are developed European countries, older EZ members that joined the 
monetary union in the initial wave of 1999/2001 (EZ12). EEEs as newer EZ members which joined the EZ since 2007 are contained in the group EZ19. The core countries are Germany, France, Belgium, the Netherlands, Luxembourg, Austria, Finland, while the periphery of the EZ12 are Greece, Spain, Portugal, Ireland, Italy. Emerging part of EZ19 consists of Slovenia, Cyprus, Malta, Slovakia, Estonia, Latvia, and Lithuania.

While EZ was not initially constituted as an OCA, this research has confirmed significant obstacles to the optimality for the period 2007-2018. The paper is structured as follows: after Introduction section, Section 2 deals with the OCA as a theoretical background of European monetary integration; openness and production diversification as OCA criteria are analysed in Section 3; macroeconomic divergences and heterogeneity within EZ are emphasized in Section 4; labor mobility and wage flexibility are explored within Section 5; Section 6 covers political OCA criteria; Section 7 outlines concluding remarks.

\section{An OCA as a theoretical background of European monetary integration: Literature survey}

Sixty years have passed since the founding of the OCA theory thanks to the seminal contributions of, among others, Mundell (1961), McKinnon (1963) and Kenen (1969). Theory of OCA was initiated in the circumstances of the Bretton Woods fixed exchange rate system, while the Maastricht Treaty followed three decades later. No major deregulation of trade and capital barriers in the world economy was observed during the creation of the OCA. However, trade and capital liberalization followed in the years of Maastricht Treaty or European monetary unification, while general framework of adjustable pegs was abandoned in the post-Bretton Woods era. With the move to flexible exchange rate regimes, research on OCA went out of fashion for a long time until the Delors Committee (Committee for the Study of Economic and Monetary Union, 1989) produced its blueprint for the EZ, which was later incorporated in the Treaty on the EU or the Maastricht Treaty. Regardless of crucial changes in international economic environment since the sixties, Mundell's work still has important implications for a group of countries that share the same currency.

There are several criteria, economic and political in nature, whereby an OCA is expected. It would be unrealistic to expect complete fulfilment of all criteria. Thus, no currency area is optimal. Notwithstanding the mentioned fact, it should be understood what makes one currency area optimal and towards what should be strived in the process of monetary unification. The economic criterion of labor mobility (Mundell, 1961) refers to minimizing the cost of asymmetric shock within monetary union. The next two economic criteria, openness and diversification of production, aim to identify countries that will be hit harder and more often by asymmetric shocks. Countries with large vulnerability to asymmetric shocks have no predisposition to participate in the monetary union. It is preferable to minimize the risk of asymmetric shocks on the basis of open economies (McKinnon, 1963) and diversification of production (Kenen, 1969). If this is not the case, then an alternative adjustment mechanism is labor mobility. If an asymmetric shock arises, labor mobility reduces its costs within monetary union. If labor 
is not mobile, then only political support remains. Therefore, after the economic criteria (labor mobility, openness and product diversification), the political criteria answer the question of whether different countries will be ready to help one another in dealing with asymmetric shocks.

Vast literature deals with the EZ and its relation with the traditional OCA criteria. The logic of the OCA theory in the case of the EZ primarily involves the estimation of the probability of asymmetric shocks. Asymmetric shocks are more common and significant if countries are less open, less integrated in terms of trade and poorly diversified in production. From the EZ perspective, members are sufficiently trade integrated and open, with acceptable production diversification (Ricci, 1997; Horvath \& Komarek, 2002; Rose, 2008). However, reality indicates susceptibility to asymmetric shocks that, according the OCA theory, leads to the identification of alternative adjustment mechanisms since exchange rate mechanism is sacrificed (Pierluigi \& Sondermann, 2018).

One currency cannot fit all unless the members move to address the underlying causes of economic divergence and asymmetries. "One size fits all" common monetary framework cannot function appropriately if members are divergent, thus susceptible to asymmetric shocks. The closer the countries are, supranational monetary authority will be more effective. OCA theory stresses the degree to which convergence is sufficient to allow economies to function synchronously within the European monetary union in order to decrease the risk of asymmetric shocks (Auf dem Brinke, Enderlein \& FritzVannahme, 2015; Franks et al, 2018). However, it is well known fact that countries in the EZ are extremely heterogeneous and diverging from an economic viewpoint. Within the EZ there are countries with large external surpluses, good GDP growth rates, low unemployment rates and high GDP per capita levels, coexisting with other countries in significantly worse position concerning mentioned economic indicators (Bonatti \& Fracasso, 2017; Pierluigi \& Sondermann, 2018). Divergence of fiscal positions between EZ members, along with sovereign debt 2010 crisis, have underlined the urge for stronger fiscal integration and close coordination of fiscal policies (De Grauwe, 2018). Macroeconomic divergences initiate heterogeneous responses of EZ members to supranational monetary impulses or "one size fits some" monetary policy (Micossi, 2015; Wortmann \& Stahl, 2016; Đorđević \& Perović, 2017; Botta, Tippet \& Onaran, 2018).

An alternative mechanism to the missing exchange rate adjustments is wage flexibility. Specifically, countries negatively affected by asymmetric shock are implementing expenditure-reducing adjustment mechanism i.e. internal devaluation. Internal devaluation implies price and wage flexibility (Gibson, Palivos \& Tavlas, 2014). However, labor market is not flexible in the EZ, while wages are rigid (Mongelli, 2008). Since the criterion of wage flexibility is not met, the next alternative mechanism is the mobility of capital and labor. In the context of globalization and deregulation, mobility of capital is implied, so the focus is on examining labor mobility among member countries. In the case of the EZ, labor is not mobile enough (Mongelli, 2008; Furrutter, 2012).

To summarize, when an asymmetric shock occurs in the EZ it is not possible to count on the exchange rate mechanism, the wage/price flexibility mechanism, nor on labor mobility. Therefore, the only remaining solution is to implement political support, i.e. financial transfers, with a homogeneity of preferences and solidarity. However, with partly expressed solidarity and homogeneity of preferences, and the absence of financial 
transfers, the EZ cannot be considered an OCA (Eichengreen, 1991; Feldstein, 1997; Dibooglu \& Horvath, 1997; Verdun, 2007; De Grauwe, 2009; Baldwin \& Wyplosz, 2012).

\section{Openess and production diversification}

Most EZ members are open and, in line with the aforementioned indicator, are good candidates for monetary integration. The economic openness is measured by the ratio of total trade (sum of exports and imports) in GDP. As a rule, smaller countries are more open because they are forced to export most of their production which coincides with large percentage of imports. EZ members (and the EU in general) have fairly high openness ratios, which according to McKinnon (1963) maximizes the benefits of sharing the same currency. The EZ19 Openness Index (average share of exports and imports in GDP) increased from $39 \%$ to $46 \%$ in the period $2007-2018$. Despite this general insight concerning the openness of EZ members, Figure 1 shows the divergence related to average ratio of exports and imports in GDP for the periphery, core and emerging countries of the EZ19. Divergence between core-periphery EZ12 is clearly observed. The core countries are, on average, more open compared to the periphery by both parameters. There is a high average openness of the emerging part of the EZ19, which particularly holds for import activities. While relatively high openness can be noted for the core and emerging part of the EZ, there is room for improvement of the OCA openness criteria in the case of the periphery.

Figure 1: Openness of the EZ19 members expressed as average export (left) and import (right) ratio in GDP in the period 2007-2018
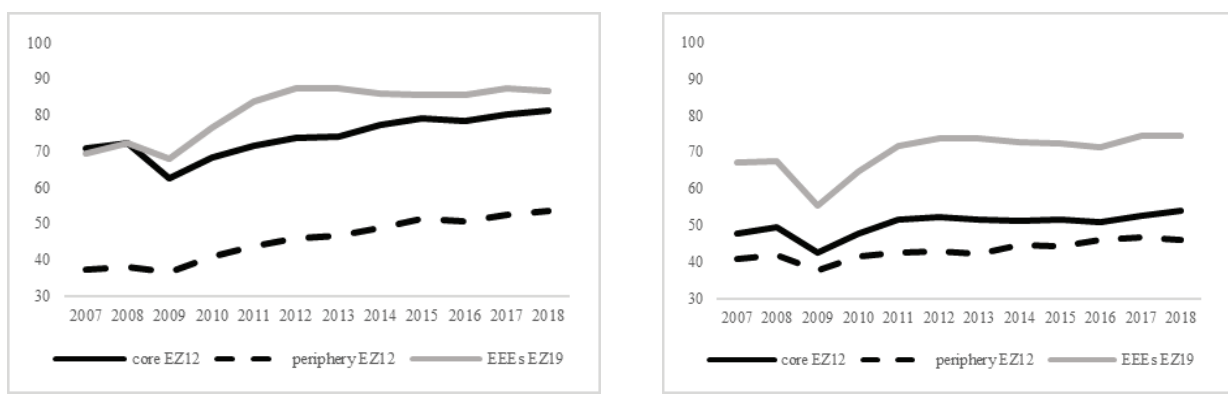

Source: Authors'calculations and review on the basis of Eurostat yearly data (https:// ec.europa.eu/eurostat/data/database).

European countries have long history of trade because trade has been at the heart of integration processes from the very beginning. A common trade policy, a common market and a single currency have all contributed to a highly concentrated trading area within Europe. Greater diversification of production by EZ members (Kenen, 1969) implies less sensitivity to asymmetric shocks as opposed to production concentration in a particular sector. The diversification of the export structure within the single European 
market according to the Standard International Trade Classification (SITC) is generally considered as acceptable. According to the 2018 data (Eurostat database), there is a dominant share in the exports of the core countries, as well as a diversity in terms of export structure (Figure 2). None of the EZ19 members has a pronounced export concentration which exposes the country to asymmetric shock in the event of a fall in demand for products of the dominant export sector. The aforementioned general conclusion does not diminish the divergence in terms of the predominantly export orientation of the core countries compared to the periphery countries and the emerging part of the EZ (Figure 2 ). The core countries dominated the exports of all SITC product groups in both years under review, 2007 and 2018. EEEs are far behind in terms of exports, and the traditional core-periphery gap has not been reduced in the post-crisis period.

Figure 2: Share of exports (\%) according SITC sectors for the core, the periphery and emerging EZ19 in 2007 (left) and 2018 (right)
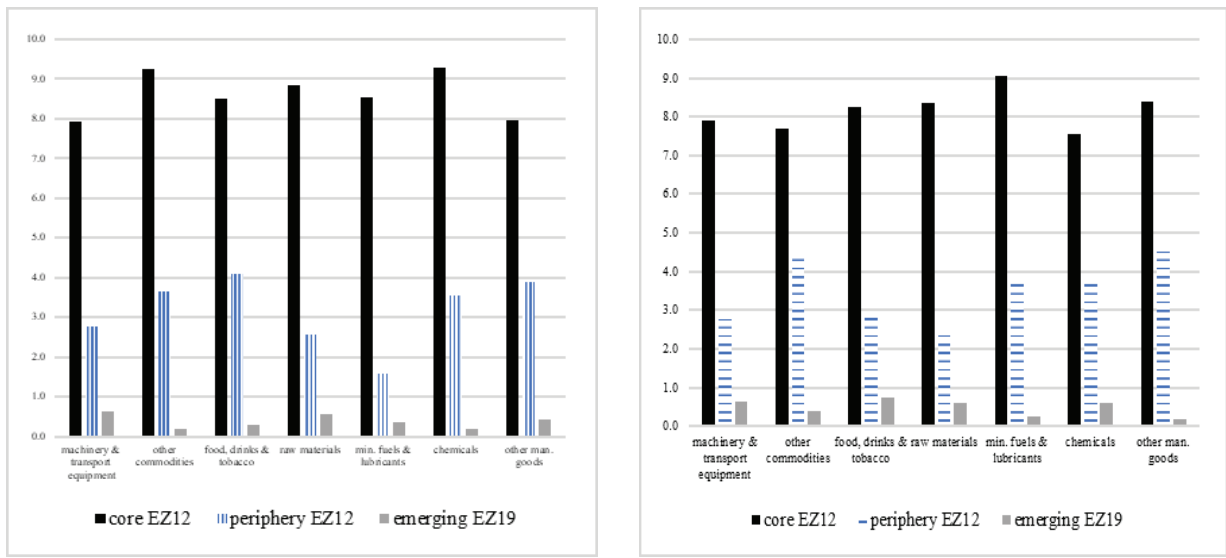

Source: Authors' review on the basis of Eurostat yearly data (https:/lec.europa.eu/ eurostat/data/database).

The specialization paradigm points to a potential increase in the EZ specialization, which reduces diversification and increases exposure to asymmetric shocks. Specialization exists within the EZ, but this process is very slow (Mongelli, Reihnold \& Papadopoulos, 2016). The largest index of specialization is in production, which has been expected due to the positive effects of economies of scale. The smallest degree of specialization is evident in the services sector. As the share of services in total GDP in the EU is around $70 \%$, specialization is not considered to be a major cause of the increasing differences between EZ members. Although the criteria of openness and production diversification are not regarded as crucial obstacle towards OCA, nevertheless the divergence between three country groups (namely core-periphery-emerging EZ part) is evident. 


\section{Divergences and heterogeneity of EZ members}

Most obvious benefit of sharing the same currency is lower transaction costs. The complexity of having many currencies in such a geographically small area (such as Europe), in which the significant difficulty of doing business is the exchange of different currencies at different rates, was avoided by the formation of a single currency area. From the other side, the most obvious cost of monetary union is the loss of some, if not complete, autonomy over fiscal and monetary policy. EZ members lose the stabilizing or counter-cyclical role of key economic policy instruments. In the event of an asymmetric shock affecting one country/region of the currency area, the question remains what is available to national economic authorities. Increasing the money supply by supranational central bank would curb unemployment in the affected countries/regions, but would trigger inflation in other countries/regions. Mundell stresses that inflation in the monetary union should be targeted so that the single central bank allows unemployment in deficit regions, negatively affected by the external shock.

The fact is that the similarity of economies makes the unique monetary policy more „one-size-fits-all“. However, the divergence of key macro-indicators of internal and external balance is the key problem for EZ stable functioning (Figure 3). While some members are facing a recession and a deficit external position, other members are in the opposite situation. Several years before the global crisis, all EZ countries were in expansion phase. However, after the crisis outbreak all EZ members went into recession. The accumulation of macroeconomic imbalances in the first decade of the EZ functioning became unsustainable, followed with a painful post-crisis adjustment with double-dip recession in the EZ between 2009 and 2012. Besides these general remarks, however, significant differences are evident in terms of their post-crisis adjustment. While some countries have regained a stable economic growth trajectory and pre-crisis output levels, other countries have experienced a recurrent economic crisis. Figure 3 reveals especially sensitive position of the periphery and emerging EZ countries compared to the core countries in the period 2007-2018.

Figure 3: The divergence of inflation rate, public debt/GDP, budget deficit and economic growth for the core, periphery and emerging part of the EZ19 members in the

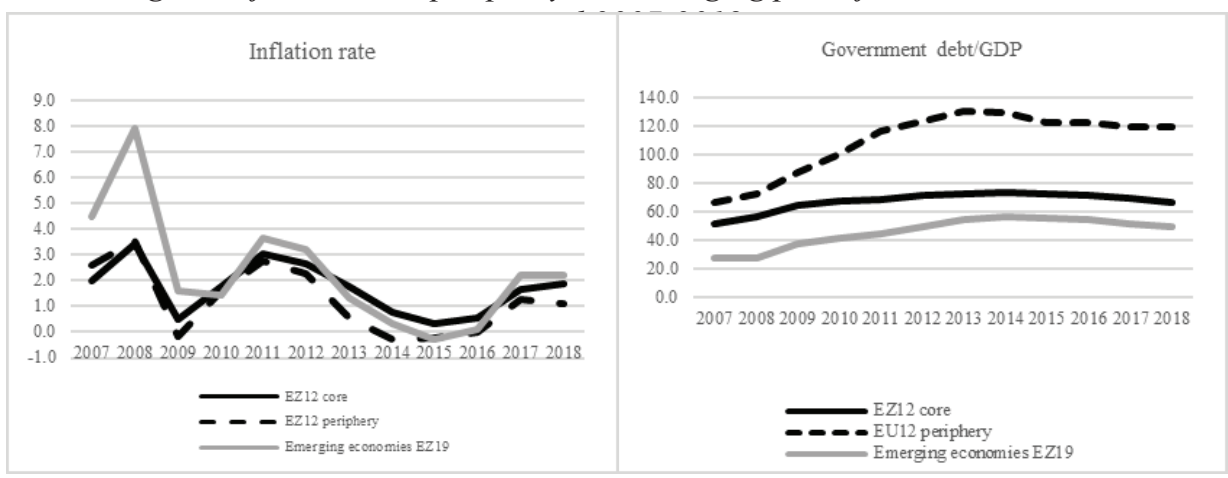




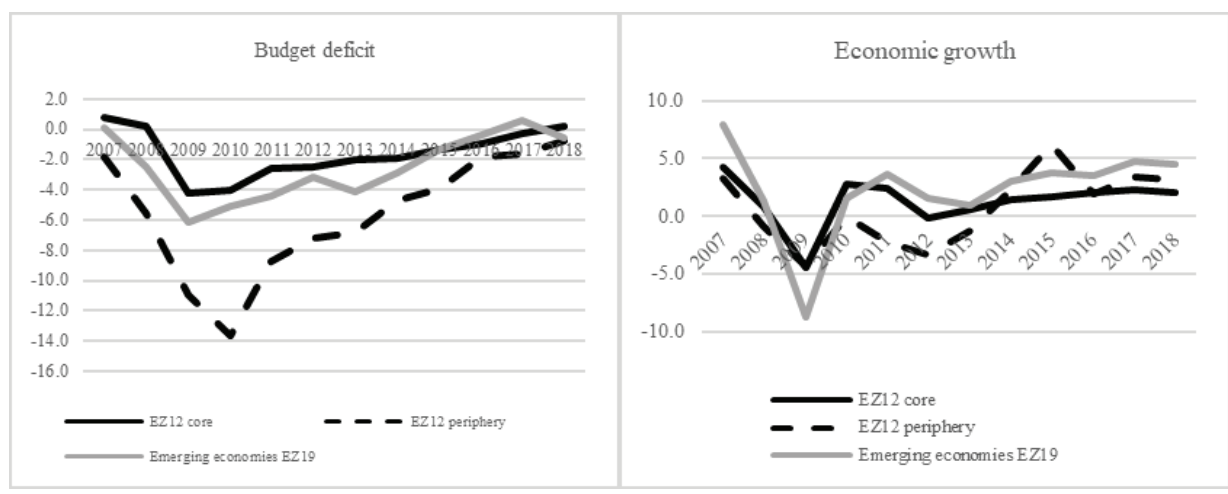

Source: authors'review based on yearly Eurostat data (https://ec.europa.eu/eurostat/ data/database).

The periphery expresses worse fiscal position according public debt/GDP and budget deficit/GDP indicators in the period 2007-2018. Also, periphery EZ countries have had unstable economic growth and are more prone to a sharp fall, significantly higher unemployment rate (Figure 4), as well as worse external position (current account deficit). Observed asymmetries and divergences even in the post-crisis period are not encouraging background for proper functioning of single European currency area. The divergences are therefore proved to be persistent.

Concerning the adjustment, members of a monetary union don't have at disposal nominal exchange rate variations as a way of expenditure-switching external adjustment, only expenditure-reducing external adjustment or internal devaluation. Exchange rate as a shock absorber is a major sacrifice for countries hit by negative external shock with recessionary consequences. Monetary union members can no longer count on currency weakening as a mechanism for current account improvement, as well as stimulation of economic activities (Wood, 2014). Having in mind persistent divergences, as well as the loss of exchange rate as a shock absorber, alternative adjustment mechanisms are therefore necessary, such as wage flexibility, labor mobility and the system of fiscal transfers.

\section{Labor mobility and wage flexibility}

One of the key stabilization mechanisms within single currency area is the mobility of factors of production (labor and capital). With decades of globalization, increasing mobility of capital is implied and European economy is no exception. Capital is extremely mobile in Europe, and European financial markets are significantly integrated. Attention is therefore directed to labor mobility. Free movement of labor is one of the four EU freedoms as an integral part of the common market (Single European Act, 1987). The Delors Report (1989) stated that a high degree of labor and wage mobility would be necessary to suppress differences in competitiveness between different countries in the functioning of the European Community. Failure to achieve competitiveness convergence would produce a sharp drop in output in those parts of the monetary union with lower productivity. 
The freedom and ability to move workers from one region (country) to another depending on job opportunities is one of the key obstacles to EZ optimality. The combination of different national cultures and languages in a small geographical area, especially when compared to large economic players (such as the USA, China, etc), is significant difficulty in EZ functioning. By comparison, labor mobility in the USA is estimated to be three to four times higher than in Europe (Schiliro, 2017). If labor mobility were preferably high, asymmetric shocks would not imply a sharp destabilization of the affected economies. In the event of rising unemployment in one EZ member, people would emigrate to other EZ members in search of work. Figure 4 shows the marked differences in the unemployment rates of the EZ19 in the period 1999-2018. There has been a persistent diversity in unemployment within the EZ since its inception, which does not indicate sufficient labor mobility. A mobile labor would imply milder differences in unemployment than is the case in the EZ. Although labor market flexibility in the EZ19 is generally low, differences are evident between members, in the sense that EEEs show higher levels of flexibility.

Figure 4: The divergence of unemployment rate in the EZ19 in the period 2007-2018

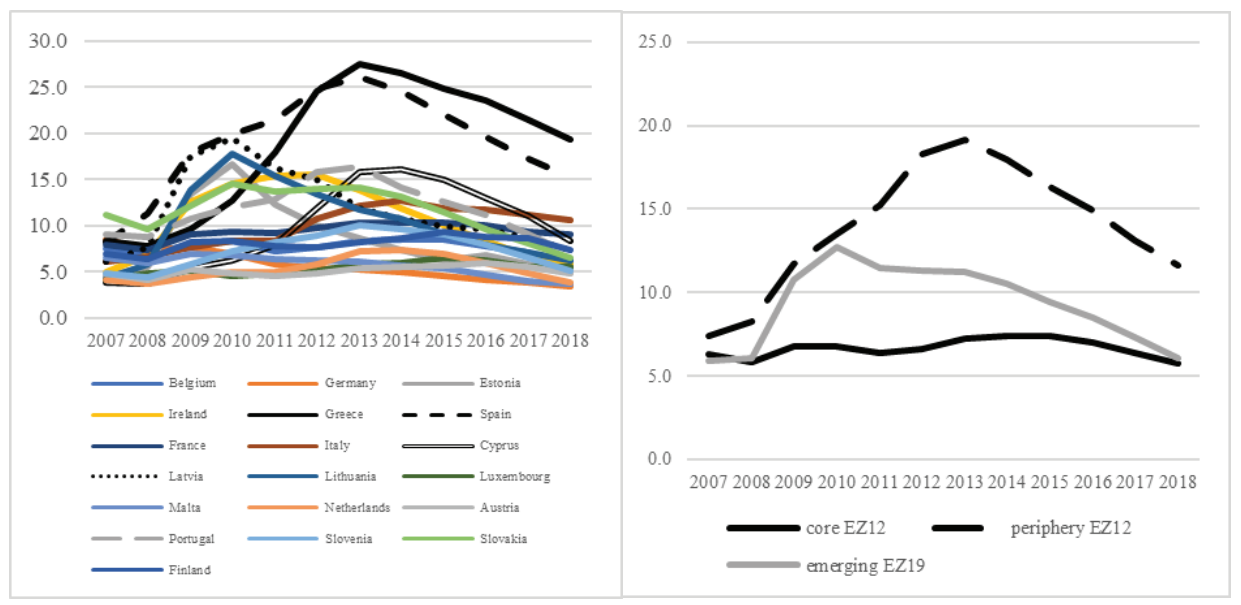

Source: Authors'review on the basis of Eurostat yearly data (https:/lec.europa.eu/ eurostat/data/database).

Figure 4 shows the divergence related to unemployment rate of the core-peripheryemerging part of EZ19. Peripheral EZ12 countries have an average higher unemployment rate, which is especially pronounced after the global economic crisis. Even the position of EEEs of the EZ19, which began accession to the EZ in the period 2007-2015 has been more favourable compared to the EZ12 periphery. The divergence of the unemployment rate, especially evident in the post-crisis period, is a sign of weak labor mobility within the EZ and rigidity of the labor market.

The main reasons for the low labor mobility between EZ members are language barriers, the historical and cultural traditions of European countries, European bureaucracy, rigid labor markets, different educational systems and the need to recognize 
diplomas and other educational qualifications. Poor mobility of people in Europe is not a temporary situation and cannot be changed in the near future. The EZ is nowhere near the concept of labor mobility predicted by OCA theory. At present, the criterion of flexibility and mobility of the OCA labor is not at a satisfactory level, lacking a mechanism for stabilizing and mitigating economic shocks (Vrňáková \& Bartušková, 2013; Furceri, Dai \& Prakash, 2014).

The rigidity of wages downwards is negative from the aspect of stable EZ functioning. A downward wage rigidity is particularly pronounced in more developed countries with stricter labor protection laws. Differences in the EZ labor market institutions contribute to different consequences (asymmetric effects) of even symmetric shocks (Heinz \& Rusinova, 2013). Wage rigidity is reflected in the pronounced differences in labor costs between EZ members (Figure 5).

Figure 5: Average labor costs (by hour, in euros) in 2008/2012/2016/2018 by EZ members (left) and divergence of core/periphery/emerging part of EZ19 (right)

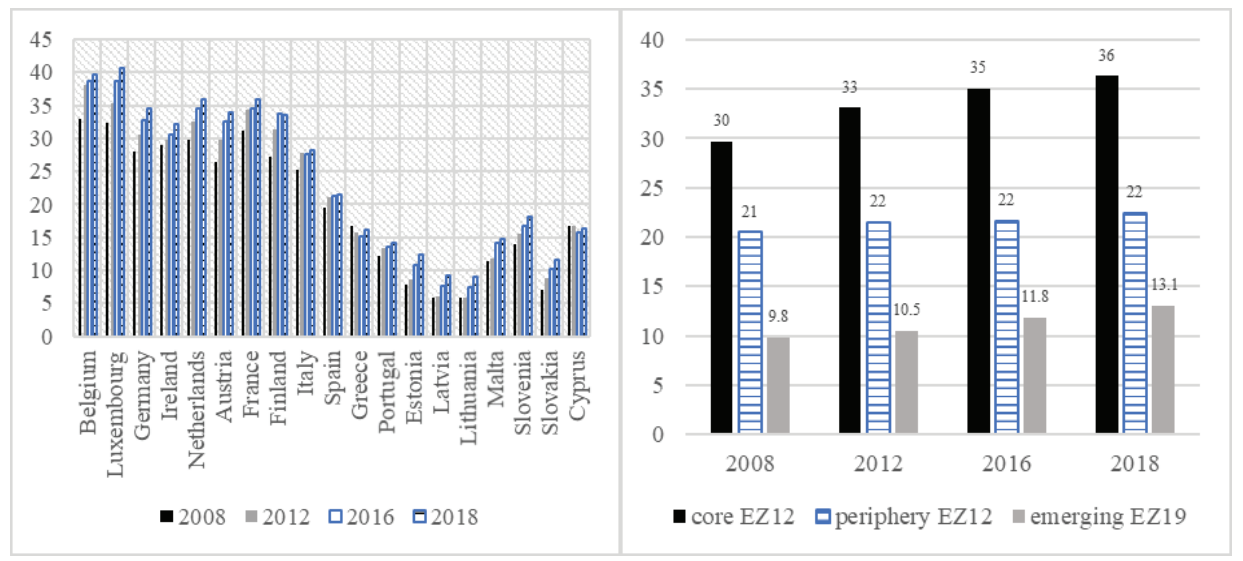

Source: Authors'review on the basis of Eurostat yearly data (https:/lec.europa.eu/ eurostat/data/database).

Figure 5 indicates an increase in labor costs per hour in the years observed, as well as significant differences between EU19 members. However, taking into account specific members, labor costs per hour ranged from $9 € /$ hour in Latvia/Lithuania to 40 $€ /$ hour in Belgium/Luxembourg. Such expressed differences in labor costs could be an impulse for greater mobility within the EZ, but the abovementioned obstacles to higher labor mobility maintain these differences between EZ members. In addition, the signal of labor market rigidity within the EZ19 is also represented with clear divergence in labor costs in all observed years between the core-periphery EZ12 and the emerging part of EZ19. Moreover, the divergence has increased over time as labor costs have significantly rose in the core, with a slight increase in the peripheral part of the EZ12. Particularly evident is the difference between developed EZ countries (core and periphery) and newer members (the emerging part of EZ19), which is a source of further problems in terms of labor market flexibility. 
Significant steps have been taken in the last decades to improve labor and capital mobility within Europe. However, greater progress is needed from the perspective of labor mobility. Monetary union is more sustainable with greater labor mobility, as labor migration from peripheral countries to core countries is a substitute for adjusting the ER in the short term. However, the long-term effects on the peripheral economy should be kept in mind. Namely, in the long run such migration undermines the capacity for economic growth of the peripheral economies due to the export of (human) capital and the increase in the productive capacity of the core countries at the expense of the periphery countries. Migration of workers from the periphery threatens the financial sustainability of the public pension system of these countries, while contributing to the financing of pensions of core countries where society is aging faster compared to the periphery.

\section{Political OCA criteria}

For an effective monetary union, the similarity of economies is not sufficient, and, as the example of the United States suggests, not a necessary condition. Countries of the USA have even more pronounced differences compared to EZ members, with the level of production diversification even lower compared to European countries. But the key difference between the USA and the EZ is in the level of political integration (Gillingham, 2003; Jovanovic, 2005; De Grauwe, 2010; Pantelis \& Maris, 2012). There is not only a lack of a mechanism for fiscal transfers but also of a coordination mechanism between fiscal and monetary policies. The EU needs an economic institution that could organise not only the monetary but also the fiscal policies in the EZ. The lagging behind of political integration and the lack of institutions that would provide assistance to countries affected by asymmetric negative shocks are major disadvantage (in addition to low labor mobility) of the EZ.

Regardless the obvious need to implement fiscal transfers, assumed by the OCA theory, they aren't yet the focus of economic and political authorities. EU common budget is strictly used for common policies and should not serve as a single fiscal policy for EZ countries. There is no willingness of member states to transfer such competences and sacrifice national fiscal policies. Political leaders have neglected theoretical and empirical studies that warned of the negative aspects of European monetary unification before its final rounding in 1999. For example, before signing the Maastricht Treaty, Eichengreen (1991) proposed a system of budget transfers, i.e. injection of liquidity from other EZ members. The need for redistributive policies that require central fiscal authority has been recognized (Dibooglu \& Horvath, 1997), that is, in addition to a supranational monetary institution, a common EU fiscal policy should be established (Verdun, 2007). Given that there is no redistributive system to mitigate asymmetric shocks in the EZ, one of the scenarios for overcoming the obstacles to EZ optimality has been the creation of an alternative adjustment mechanism through the fiscal transfer system (De Grauwe, 2010; Gabrić-Molnar \& Soos, 2016).

Despite the political will to initiate and deepen European economic integration, the political criteria of the OCA related to homogeneity of preferences and solidarity criteria are at best only partially met. Divergence in terms of inflation rate, especially in relation to the core-periphery, is not affirmative for meeting the political criterion of 
homogeneity of preferences. Often, the two extremes of heterogeneity of preferences regarding the common monetary policy are cited by Germany as a typically low-inflation economy on the one hand, and Greece and Italy with traditionally higher inflation rates on the other. In addition to inflation preferences, there is also a gap in public finance indicators (budget deficit and public debt) in the core-periphery ratio (see Figure 3), which is also related to inflation-employment preferences.

The solidarity criterion answers the question of the extent to which citizens are prepared to relinquish national sovereignty for the common interest of the EZ. The renunciation of monetary sovereignty is a great indicator of political willingness, but the need to maintain fiscal and other aspects of national sovereignty still exists. The most efficient way of balancing between systemic differences and macroeconomic divergences stressed in the sections above, is to establish a system of EU federal fiscal transfers. If such a system existed in the EZ, those countries most affected by the global 2008 crisis (as for example, Greece and Spain) would receive assistance from economically stronger members (as Germany), which would greatly mitigate the crisis in the EZ. However, the EU budget is small, just above 1\% of GDP, and is spent almost entirely on structural funds, European Commission labor costs and the Common Agricultural Policy. A serious system of financial transfers, in line with the OCA criterion, would require significant growth in the EU budget, which brings us to the political criterion of solidarity.

The traditional OCA theory has largely ignored the implications of monetary unification for fiscal policymaking, as well as potential conflicts between supranational monetary and national fiscal authorities. Monetary unification affects the interactions between national fiscal authorities with consequences for the monetary and fiscal policy mix, as well as macroeconomic outcomes. The conflict between an independent ECB and the decentralized fiscal authorities about the macroeconomic objectives is of huge importance for the EZ (in)stability. Namely, the ECB attaches a large weight to stabilizing inflation at a low level, while national fiscal authorities are more concerned with a high and stable level of economic activity (Beetsma \& Giuliodori, 2010). Since monetary policy is not under the control of national authorities, over excessive fiscal expansion is seen as main problem within the monetary union (Alessandrini et al, 2014; Schiliro, 2017). Fiscal divergences within $\mathrm{EU}$ members have been evident from the period before $\mathrm{EZ}$ creation until nowadays. Glavaški \& Beker (2019) and Dragutinović-Mitrović, Glavaški \& Beker Pucar (2019) explored the fiscal sustainability and the necessity of fiscal transformations in the period 1995-2018. The authors have outlined weak fiscal sustainability with heterogeneous evidence of fiscal adjustments in the EU economies, emphasizing that new mechanisms for strengthening of fiscal frameworks could have a potential to improve fiscal performances.

\section{Conclusion}

EZ was not initiated as an OCA, and through functioning (despite visible shifts) the fulfilment of key OCA criteria was still not ensured. Descriptive analysis presented in the paper reviewed the fulfilment of OCA criteria in the case of EZ19 in the period 2007-2018 for the core, periphery, as well as EEEs. The analytical approach to the (in)optimality of the EZ serves as the basis for reconsidering previously mentioned 
stances and also as a basis for identifying the space for change towards more stable EZ functioning.

The analysis confirmed that EZ cannot be regarded as an OCA due to persistent macroeconomic divergences between member states, inadequate labor mobility, insufficient wage flexibility, the absence of political will towards creation of more efficient fiscal union. According the OCA logic, the likelihood of asymmetric shocks should be minimized first. Given the high degree of mutual trade and openness of the EZ members, with acceptable product differentiation, it can be concluded that there is no pronounced susceptibility to asymmetric shocks by these criteria. However, the analysis also highlights that there is a dominant share in the exports of the core countries and that the core countries are, on average, more open compared to other EZ members. The accumulation of imbalances in the first decade of the EZ became unsustainable and triggered a painful post-crisis adjustment. Despite adjustments of some macroeconomic indicators in the second decade of EZ, macroeconomic divergences between core, periphery and EEEs still persist, especially related to the public finances, unemployment and external balance.

According the OCA logic, if asymmetric shocks occur, alternative adjustment mechanisms must be provided. Given the exclusion of the nominal exchange rate as an automatic stabilizer, the adjustment option is an internal devaluation or expenditurereducing adjustment within the EZ. One of the key obstacles to assessing EZ optimality is here. EZ does not meet OCA's price and wage flexibility criteria. The labor market is not flexible, wages are generally downward rigid (especially in more developed economies). Even at downward rigid wages, internal devaluation can be avoided or limited by labor mobility. Labor in economies adversely affected by external shocks should shift towards more stable economies within the single currency area. Labor within the EZ is not mobile due to cultural, linguistic and administrative barriers.

Finally, the political criteria represent one of the key disadvantages of the EZ, because there is no transfer payment system to mitigate asymmetric shocks. The EZ is nowhere near the optimum currency area. Many obstacles, especially poor labor mobility, are not easy to remove. Divergences of EZ members and unfulfilled economic OCA criteria could be mitigated with the accomplishment of political OCA criteria. Thus, fiscal co-operation and fiscal union based on stronger political will, with higher homogeneity of preferences and solidarity criteria, present the crucial challenge for further improvements of EZ functioning.

\section{References}

Alessandrini, P., Fratianni, M., Hughes, A., \& Presbitero, F. (2014). External imbalances and fiscal fragility in the euro area. Open Economies Review, 25(1), 3-34.

Auf dem Brinke, A., Enderlein, H., \& Fritz-Vannahme, J. (2015). What kind of convergence does the euro area need? Gütersloh: Bertelsmann Stiftung und Jacques Delors Institut - Berlin.

Baldwin, R., \& Wyplosz, C. (2012). The economics of European integration. Berkshire: McGraw-Hill Higher Education. 
Beetsma, R., \& Giuliodori, M. (2010). The macroeconomic costs and benefits of the EMU and other monetary unions: An overview of recent research. Journal of Economic Literature, 48, 603-641.

Beker Pucar, E., \& Glavaški, O. (2019). Macroeconomic external (im)balances within the EZ: Core vs periphery. Economic Themes, 57(3), 257-272.

Bonatti, L., \& Francasso, A. (2017). Adressing the core-periphery imbalances in Europe: Resource misallocation and expansionary fiscal policies. EconPol working paper November volume 1, 06/2017.

Botta, A., Tippet, B. \& Onaran, O. (2018). Core-periphery divergence and secular stagnation in the EZ - Macroeconomic evidence and policy proposals beyond conventional monetary policy. Foundation For European Progressive Studies Policy Paper, June 2018.

Committee for the Study of Economic and Monetary Union. (1989). Report on Economic and Monetary Union in the European Community. Luxembourg: Office for Official Publications of the European Communities.

De Grauwe, P. (2010). Crisis in the EZ and how to deal with it. Centre for European Policy Studies Policy Brief, No. 204, February.

De Grauwe, P. (2018). Core-periphery in the EZ. Paper presented at the conference "The future of central banking" in honour of Vitor Constancio, Frankfurt, 16-17 May.

Dibooglu, S., \& Horvath, J. (1997). Optimum currency areas and the European monetary unification. Contemporary Economic Policy, 15(1), 37-49.

Dragutinović Mitrović, R., Glavaški, O., \& Beker Pucar, E. (2019). Fiscal Sustainability in Flow Model: Panel Cointegration Approach for the EU-28. In Ovidius University Annals Economic Sciences Series XIX (pp. 15-24). Constanta: Ovidius University.

Đorđević, M., \& Perović, D. (2017). Crisis impact on changes in implementing monetary policy of central banks. Ekonomika, 62(3), 57-67.

Eichengreen, B. (1991). Is Europe an optimal currency area? National Bureau of Economic Research Working Paper 3579.

Feldstein, M. (1997). EMU and international conflict. Foreign Affairs, Nov-Dec, 6073.

Furceri, D., Mai, D., \& Prakash, L. (2014). Regional labor market adjustments in the United States and Europe. International Monetary Fund Working Paper $\mathrm{WP} / 14 / 26$.

Furrutter, M. (2012). The EZ: An optimal currency area? IFIER Papers, 02/2012.

Gabrić-Molnar, I., \& Soos, E. (2016). The instruments of the European union crossborder regional cooperation. Anali Ekonomskog fakulteta u Subotici, 36, 3-24.

Gibson, H. D., Palivos, T., \& Tavlas, G.S. (2014). The crisis in the euro area: An analytic overview. Journal of Macroeconomics, 39, 233-239.

Gillingham, J. (2003). European Integration 1950-2003: Superstate or new market economy? Cambridge: Cambridge University Press. 
Glavaški, O., \& Beker Pucar, E. (2019). Heterogeneity of fiscal adjustments in European Union economies: Common correlated effects approach. Paper presented at the 29th Eurasian EBES Conference, 10-12th October, Lisbon, Portugal.

Heinz, F., \& Rusinova, D. (2011). How flexible are real wages in EU countries? Working Paper 1360.

Horvath, R., \& Komarek, L. (2002). Optimum currency area theory: An approach for thinking about monetary integration. Warwick economics research papers no 647.

Jovanovic, M. (2005). The economics of the European integration: Limits and prospects. Massachusetts: Edward Elgar.

Kenen, P. B. (1969). The optimum currency area: An eclectic view. In Mundell \& Swoboda, (Eds.), Monetary problems of the international economy. Chicago: University of Chicago Press.

McKinnon, R. (1963). Optimum currency areas. American Economic Review, 53(4), 509-517.

Micossi, S. (2015). The monetary policy of the European Central Bank. Centre for European Policy Studies special report no. 109.

Mongelli, F. P. (2008). European economic and monetary integration, and the optimum currency area theory. European Economy, Economic Papers 302.

Mongelli, F. P., Reihnold, E., \& Papadopoulos, G. (2016). What's so special about specialisation in the euro area? European Central Bank occasional paper no. 168.

Mundell, R. A. (1961). A theory of optimum currency areas. The American Economic Review, 51(4), 657-665.

Pantelis, S., \& Maris, G. (2012). Reassessment of the OCA criteria in the euro area: The case of Greece. Int. J. Monetary Economics and Finance, 5(2), 124-138.

Pierluigi, B., \& Sondermann, D. (2018). Macroeconomic imbalances in the euro area: Where do we stand? European Central Bank occasional paper no. 211.

Ricci, L. A. (1997). A model of an optimum currency area. International Monetary Fund working paper 97/76.

Rose, A. K. (2008). Is EMU becoming an optimum currency area? The evidence on trade and business cycle synchronization. Berkeley: University of California.

Schiliro, D. (2017). Imbalances and policies in the EZ. Munich Personal RePEc Archive Working Paper 82847.

Verdun, A. (2007). Economic and monetary union. In M. Cini (Ed.), European Union Politics (pp. 324-229). Oxford: Oxford University Press.

Vrňáková, I., \& Bartušková, H. (2013). Is euro area an optimal currency area and what barriers could obstruct its future development? ACTA VŠPS, 2(7), 123-144.

Wood, R. (2014). EZ macroeconomic framework: Reducing internal and external imbalances. Munich Personal RePEc Archive 53569.

Wortmann, M., \& Stahl, M. (2016). One size fits some: A reassessment of EMU's core-periphery framework. Journal of Economic Integration, 31(2), 377-413. 